\title{
Efficiency of the Erosion Protection Methods Involving Biologizing Agriculture in the Steppe and Forest-steppe Areas of Cultivated Land in Siberia
}

\author{
Egor Yakovlevich Chebochakov \\ Department of Agro-soil Science and Land Use, Research Institute of Agricultural Problems of Khakassia, Abakan, Russia \\ Email address: \\ echebochakov@mail.ru \\ To cite this article: \\ Egor Yakovlevich Chebochakov. Efficiency of the Erosion Protection Methods Involving Biologizing Agriculture in the Steppe and Forest- \\ steppe Areas of Cultivated Land in Siberia. International Journal of Nutrition and Food Sciences. Vol. 9, No. 1, 2020, pp. 6-9. \\ doi: $10.11648 /$ j.ijnfs.20200901.12
}

Received: January 20, 2020; Accepted: February 17, 2020; Published: February 25, 2020

\begin{abstract}
The research has been carried in the steppe zone of the Minusinsk Hollow and forest-steppe of the Altai Ob Region. The paper presents the results of studying the efficiency of erosion protection methods using biologizing agriculture and technologies of soil treatment. The authors have analyzed long-term data provided by numerous research institutions located in different agro-ecological conditions in the forest-steppe and steppe areas of cultivated land. Long-term field experiments carried out to study and make a comparative analysis of soil treatment technologies in green manure fallows have shown different soil conservation efficiencies in various soil climatic conditions of the Middle Siberia. In the steppe area of cultivated land, in the case of erosion-hazard soil, it is worth using stubble mulch tillage treatment, which allows preserving plant residues on the soil surface in order to increase the soil protection efficiency of green manure fallows. After this type of treatment no removal of fine soil by wind was observed on black soil, while in the case of tillage the soil removal amounts to 2,5 - 8,1 tons per hectare per year. In the steppe area on slope lands, winter stubble residues allow one to completely prevent the soil wash out in spring. The number of days with dust storms after the Virgin Lands Campaign in Khakassia in $1961-1965$ amounted to $5-13$. At present, with the decreased areas of strongly eroded plough land and increased volume of fallow land, dust storms do not occur. A fallow grown crop (summer planted oats) and, on the slope lands, mulching with rape completely prevented the spring wash out. The grain yield from a hectare of the crop rotation area in the case of sweet clover tillage and stubble mulch plowing was almost the same: 1,64 and 1,76 tons per hectare, respectively. Treatment of the deposit land followed by spraying with Tornado herbicide in August reduces soil erosion 2.2 times compared to its introduction in June.
\end{abstract}

Keywords: Agriculture, Biologization, Crop Rotation, Treatment, Deflation, Erosion, Soil, Grain Yield

\section{Introduction}

The relevance of different methods of biologization in agriculture is determined by considerable changes connected with new socio-economic and agro-ecological conditions, namely, with the redistribution of agricultural land between farm units of various types, decreasing area of plough land and increasing amount of fallow land, as well as lowering soil productivity and growing problems of environment protection including soil protection from erosion. [1 - 3]. One of the vivid examples of introducing environmental science into agriculture is continuously keeping soil surface under the cover of plants or plant residues, i.e. mulching. Mulching performs the function of the steppe mat protecting soil from erosion. [4-11].

In Russia, agricultural lands subjected to erosion and deflation amounted to 104 million hectares in 1990 while in 1997 this amount was 126 million hectares [12]. Soil protection from erosion remains to be the most urgent problem in the arid steppe conditions of the southern Siberia (The Republic of Khakassia, the Republic of Tyva etc.). Here, $70-80 \%$ of the plough land are subjected to deflation and water erosion [13]. At present, as well as in the $\mathrm{XX}$ century, soil degradation was observed in the case of violating agrotechnologies. However, in the steppe and forest-steppe regions of Siberia green manuring was 
suggested [3]. The research goal has been to determine the efficiency of erosion protection methods involving biologization agriculture in the steppe and forest-steppe lands of Siberia.

\section{Research Methods}

The efficiency of different biologization methods and techniques of soil treatment was estimated taking into account their soil protection potential and crop yields in different agro-ecological conditions. The investigations involved field experiments.

In the steppe area of the Minusinsk Hollow the impact and consequences of clean and sweet clover fallow as well as different methods of soil treatment were studied. Each experiment assumed four replications, the plots were located according to a system. Yellow sweet clover was planted under the cover of oats. Upon reaching the budding phase it was mown and crushed with a forage harvester KSK-100 or with a harvester-shredder. A clean fallow was prepared using the accepted zone technology [13]. Erodibility of southern blacksoil was studied in the case of different treatment methods. The experiments assumed three replications, the plots were located according to a system.

During the field experiments $(1984-1989)$ in the foreststeppe of the Altai $\mathrm{Ob}$ Region, a comparison was made of clean, seed and green manure fallows and technologies of their preparation for the crop rotation fallow-wheat-wheatoats. Sweet clover, oats and rape were used as fallow grown crops. Each experiment was repeated three times, the plot area was $600 \mathrm{~m}^{2}$, the registration plot being $100 \mathrm{~m}^{2}$ [14]. Regional varieties of crops were used in the experiments.

\section{The Research Results}

Of great significance for increasing anti-erosion resistance are not only the methods of biologization in agriculture but also soil treatment technologies which allow preserving plant residues in the form of mulch on the soil surface. In the experiments carried out by I. S. Antonov et al., data were obtained concerning the advantage of soil treatment using stubble mulch plow (Table 1).

Table 1. Loss of fine soil depending on the method of fallow soil treatment (1988-1992).

\begin{tabular}{llc}
\hline Option & Deflation of fine soil, tons per hectare & Humus loss, tons per hectare \\
\hline Collective farm «Tabatsky» & 8,1 & 0,6 \\
Green manure fallow, sweet clover (green manuring) & 0,0 & 0,0 \\
Green manure fallow, sweet clover (stubble mulch plowing) & & \\
Collective farm «Tuimsky» & 2,5 & 0,1 \\
Green manure fallow, sweet clover (green manuring) & 0,0 & 0,0 \\
Green manure fallow, sweet clover (stubble mulch plowing) & \\
\hline
\end{tabular}

Green manuring led to the wind removal of fine soil (2.5 - 8.1 $\mathrm{t} / \mathrm{ha}$ ). During stubble mulch plowing, plant residues remained on the surface and protected the soil. Summer sowing of crops in a fallow field was of great soil-protective value. According to our data, sowing of oats in 1988 in the OJSC "Rossiya" in late July - early August within an area of 400 ha prevented the removal of fine soil in spring, 1989. Similar data were obtained as a result of research carried out in the forest-steppe of the Altai Ob Region and steppe zone of Canada [14].

Long-fallow vegetation also effectively protects soil from deflation and water erosion. The number of days with dust storms after the Virgin Lands Development (in 1961-1965) was up to 5-13 per year. In the Republic of Khakassia, deflationary processes ceased with a decrease in the area of arable land due to the transfer of highly and medium eroded soils to the fallow.

In modern conditions, the steppe vegetation is being restored in such lands and deflation basins, where dust storms used to occur. These areas are overgrown with perennial cereal and bean herb, shrubs and trees (Figure 1).

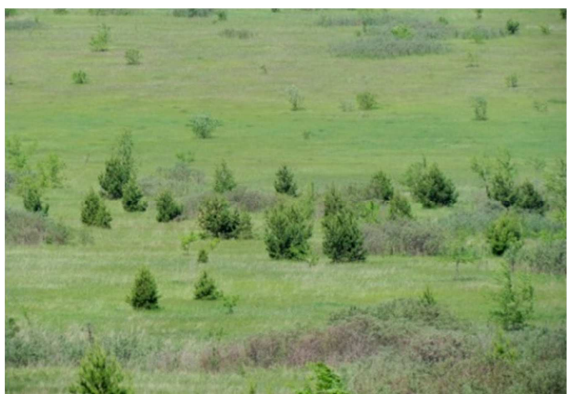

Figure 1. General view of long fallow lands in the Beya submontane steppe (2017).

A soil protection method for soil treatment using herbicides is necessary for the development of fallow lands.

Table 2. Erodibility of fallow soil in the case of different treatment methods, $g$.

\begin{tabular}{|c|c|c|c|c|c|c|c|}
\hline \multirow{2}{*}{\multicolumn{2}{|c|}{ Technological operation }} & & & \multicolumn{2}{|c|}{ Chestnut soil } & \multirow{2}{*}{$\begin{array}{l}\text { Southern black soil } \\
2015 \text { r. (spring) }\end{array}$} & \multirow{3}{*}{ Average } \\
\hline & & & & 2012 г. & 2013 г. & & \\
\hline 1 & 2 & 3 & 4 & 5 & 6 & 7 & \\
\hline Herbicide & Disk plowing & Stubble mulch plowing at a depth of $10-12 \mathrm{~cm}$ & Cultivation & 55,9 & 13,5 & - & 34,7 \\
\hline Herbicide & Disk plowing & Stubble mulch plowing at a depth of $14-16 \mathrm{~cm}$ & Cultivation & 43,9 & 17,8 & 72,4 & 44,4 \\
\hline Herbicide & Disk plowing & Stubble mulch plowing at a depth of $14-16 \mathrm{~cm}$ & Cultivation & 10,7 & - & $32,4 *$ & 21,5 \\
\hline Herbicide & Disk plowing & Stubble mulch plowing at a depth of $14-16 \mathrm{~cm}$ & Tillage & 9,2 & 20,4 & 81,3 & 37,0 \\
\hline
\end{tabular}

* - plowing at $18-20 \mathrm{~cm}$ in spring 
Plowing the fallow soil at a depth of $18-20 \mathrm{~cm}$ in MayJune with further disk plowing, fine stubble mulch plowing and treatment with Tornado 500 herbicide in August reduces the erodibility as compared with the methods including fine soil treatment with the herbicide being introduced in the beginning of summer.

The method of plowing fallow soil with the introduction of Tornado 500 herbicide in August is more perspective.

According to the data obtained, the soil erodibility in the case of fallow plowing with the introduction of «Tornado 500» herbicide in late May-early June was equal to $72,4 \mathrm{~g}$, and in late August - 32,4 g (the acceptable limit being $34 \mathrm{~g}$ ). This can be explained by large storage of plant residues $(73,8$ and 133,8 $\mathrm{pcs} / \mathrm{m}^{2}$ respectively) on the soil surface. During the years of the large-scale development of fallow lands in «Tselinnoye» Ltd. the grain production increased by 3.9 times, that of milk - by 2.6 times, and meat - by 2.1 times. On slope lands of the forest-steppe of the Altai Ob Region, the soil loss from erosion in the case of mouldboard plowing of fallow lands amounted to $36.7 \mathrm{~m}^{3} /$ ha during 5 years on average. [15].

Under these conditions, it is reasonable to use the fallow lands for autumn-summer growing of rape, its mulching and surface plowing down of sweet clover. Plant residues left on the soil surface almost completely prevent spring wash out. The method of stubble mulch plowing with herbicide spraying reduces the spring soil loss twice.

Along with the effective soil protection from deflation and water erosion the stubble mulch plowing and surface plowing down of fine vegetative mass of the fallow grown crops scattered on the soil surface provides almost the same crop productivity and grain yield per hectare of crop rotation (Table 3).

Table 3. Grain crop yield and productivity of crop rotation, depending on the method of green manure fallow treatment, t/ha.

\begin{tabular}{|c|c|c|c|c|}
\hline \multirow{2}{*}{ Option } & \multicolumn{3}{|c|}{ Crop yield in rotation, $t / h a$} & \multirow{2}{*}{ Grain yield per 1 ha, tons } \\
\hline & Fallow wheat & Wheat & Oats & \\
\hline \multicolumn{5}{|c|}{ Forest-steppe of the Altai Ob Region (1985-1989) } \\
\hline 1. Autumn mulching with rape & 2,71 & 1,96 & 2,32 & 1,65 \\
\hline 2. Sweet clover green manuring & 2,53 & 2,12 & 2,25 & 1,61 \\
\hline 3. Surface plowing down of sweet clover & 2,57 & 2,02 & 2,12 & 1,58 \\
\hline $\mathrm{HCP}_{05}$ & 0,16 & 0,14 & 0,23 & \\
\hline \multicolumn{5}{|c|}{ Dry steppe of the Minusinsk Hollow (1989-1991)* } \\
\hline 2. Stubble mulch plowing & 2,53 & 3,00 & $1,48 * *$ & 1,76 \\
\hline $\mathrm{HCP}_{05}$ & 0,38 & 0,24 & & \\
\hline
\end{tabular}

*- grain crops, **- oats for crop haylage

So, the yield of the first crop of rotation (wheat) in the forest-steppe of the Altai $\mathrm{Ob}$ Region upon sweet clover green manuring was $2.53 \mathrm{t} / \mathrm{ha}$, while in the case of the surface plowing down it amounted to $2.57 \mathrm{t} /$ ha at $\mathrm{HCP}_{05}=$ 0.16. The difference in the yield of the second and third crops for these soil treatment methods was also insignificant $-0.10-0.13 \mathrm{t} / \mathrm{ha}\left(\mathrm{HCP}_{05}=0.14\right.$ and 0.23 , respectively). In general, in the forest-steppe and arid steppe agricultural areas, the crop productivity and grain yield in crop rotations with different soil cultivation methods and fallow green manuring were almost the same. It should be noted that plant residues in the case of stubble mulch plowing and surface plowing down effectively protects soil from wind and water erosion.

\section{Conclusion}

In the steppe agricultural area of Siberia in erosion-hazard lands, to increase the soil-protective role of fallow green manure, it is advisable to use stubble mulch plowing, which allows preserving plant residues on the soil surface. In the case of fallow green manuring, the removal of fine soil by wind in black soil reached $2.5-8.1 \mathrm{t} / \mathrm{ha}$. The winter stubble residues made it possible to almost completely prevent the spring soil wash out.

The number of days with dust storms after the development of virgin and fallow lands in Khakassia in
1961-1965 reached 5-13 per year, with a decrease in the area of highly eroded arable land and an increase in the area of fallow lands, no dust storms were observed. The grain yield from 1 ha of the crop rotation area in the case of sweet clover green manuring and stubble mulch plowing was almost the same: 1.64 and $1.76 \mathrm{t} / \mathrm{ha}$, respectively.

\section{References}

[1] Agroecological assessment of land, design of adaptive landscape systems of agriculture and agricultural technologies. Methodological guidance. pp. 784. 2005.

[2] A. M. Berzin. Green fertilizers in Central Siberia. pp. 395. 2002.

[3] A. M. Berzin, V. A. Polosina. Improving the efficiency of pure and sideral vapors in the forest-steppe and steppe regions of Siberia. Bulletin of Krasnoyarsk state University. No. 3. Pp. 39-44. 2018.

[4] V. I. Kiryushin, S. V. Kiryushin. "Agrotechnologies". pp. 464. 2015.

[5] V. V. Kulintsev, V. K. Dridiger, E. I. Godunova etc. Effekt of No-till Technology on The Available Moisture Content and Soil Density in The Crop Rotation. Research Journal of Pharmaceutical, Biological and Chemical Sciences. № 8 (6). 2017. P. 795-799. 
[6] Lessiter Frank. 29 reasons why many growers are harvesting higher no-till yields in their fields than some university scientists find in research plots. No-till Farmer. 2015 Vol. 44, num. 2. P. 8.

[7] V. K Dridiger., E. I. Godunova etc. Effekt of No-till Technology on erosion resistance, the population of earthworms and humus content in soil. Research Journal of Pharmaceutical, Biological and Chemical Sciences. № 9 (2). 2018. P. 766-770.

[8] Trofimov I. A., Trofimova L. S., Yakoleva E. P. Problems and prospects of agriculture in Russia. Fertility and evaluation of agricultural productivity. Tyumen: GAU of the Northern TRANS-Urals, 2018. Pp. 294-302.

[9] Yakovleva E. P. State of agricultural landscapes of the Omsk region. Fertility and assessment of agricultural productivity. Tyumen, 2018. Pp. 339-348.

[10] Chebochakov E. Ya., Yedimeichev Yu. F., Shaposhnikov G. M., Murtaev V. N. "Anti-Erosion efficiency of agricultural biologization techniques in the steppe and forest-steppe agrolandscape areas of Central Siberia". Kormoproizvodstvo No. 1. 2019. with. 27-30.
[11] Kiryushin V. I. Scientific and innovative support of agricultural development priorities. Achievement of agricultural science and technology. Vol. 33 no. 3. 2019. Pp. 510 .

[12] G. A. Romanenko, I. G. Kruzhilin, M. S. Grigorov. Integrated land reclamation for sustainable development and neutralization of desertification in arid regions of Russia. The problem of desertification and protection of biological diversity of natural and economic complexes of arid regions of Russia. "Modern notebooks". pp. 480. 2003.

[13] I. S. Antonov, S. M. Charkov, N. A. Gradoboeva. Sweet clover green manure in agriculture of the Republic of Khakassia. "Khakass state University". p. 102. 2004.

[14] Sub-regional national programme of action to combat desertification for the South of Central Siberia of the Russian Federation. p. 295. 2000.

[15] A. A. Tumanov. Clean, occupied and sideral pairs and technologies of their preparation on chernozems of foreststeppe of the Altai territory. Problems of experimental agricultural chemistry. Scientific-pedagogical agro-chemical school of academician G. P. Gamzikova. Pp. 292-298. 2013. 